Pamiętnik Literacki 2016, 2, s. 67-84
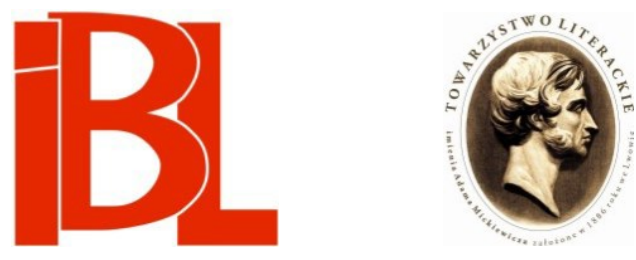

\title{
Co się śni zwierzętom? Stefan Flukowski i
}

\author{
psychoanaliza
}

\author{
Piotr Krupiński
}


PIOTR KRUPIŃSKI Uniwersytet Szczeciński

\section{CO SIE ŚNI ZWIERZETOM? STEFAN FLUKOWSKI I PSYCHOANALIZA}

Pośmiertnie wydany tom prozatorski Stefana Flukowskiego Zapach księżyca ${ }^{1}$, w którym przedrukowane są jego utwory z Dwudziestolecia międzywojennego ${ }^{2}$, zaskakuje doborem protagonistów. W wypadku aż trzech $\mathrm{z}$ czterech utworów składających się na tę skromnej objętości książeczkę główną rolę odgrywają zwierzęta. Pośrednio taki dobór bohaterów zapowiada już pierwsza strona okładki, na której widzimy kota przycupniętego na dachu kamienicy „w księżycowa jasną noc”. Kot to jednak dość niezwykły, gdyż autor projektu graficznego postanowił wyposażyć go w ludzką fizys, ba, człowiecze rysy zostały dodatkowo podkreślone... szminką.

Jeśli pozwalam sobie zatrzymać się nieco dłużej nad powierzchnią okładki, to czynię tak dlatego, że choć sam jej koncept nie wydaje mi się artystycznie najdoskonalszy (po trosze przypomina średnio udany pastisz stylistyki Kazimierza Mikulskiego), to mimo wszystko dobrze wprowadza nas w główne wewnątrztekstowe napięcia utworów Flukowskiego, przede wszystkim eksponując trudność, z jaką zmierzyć się musi każdy pisarz, który za cel stawia sobie próbę spojrzenia na świat z perspektywy innej niż ludzka. A z takim właśnie eksperymentem narracyjnym mamy do czynienia $\mathrm{w}$ analizowanej tu prozie jednego $\mathrm{z}$ kwadrygantów. Zdecydowawszy się na udzielenie głosu zwierzętom, nawet jeśli $z$ konieczności musiało to odbyć się w trybie głęboko zmediatyzowanym, pisarz nieuchronnie więc zmierzyć się powinien $z$ dziedzictwem antropocentryzmu, bariera, jak podpowiadają filozofowie, nieprzekraczalną i może właśnie dlatego tak prowokująca artystów. Po raz ostatni kierując wzrok na naszą okładkę, należałoby zatem zapytać, czy rzeczywiście stało się tak, że wciąż młody (bo niespełna 30-letni) twórca, debiutujący w nowym dla siebie rzemiośle (wszak Flukowski dał się zapamiętać przede wszystkim jako poeta), poniósł ambitna porażkę, w której wyniku jego narracja utkwiłaby gdzieś pomiędzy ludzkimi ustami (vide: projekt okładki) a brzegiem tego, co pozaludzkie. Zagadkę tę postaram się rozwikłać w dalszej części swoich rozważań.

Zanim do tego dojdzie, chciałbym wszakże wskazać na pasmo dodatkowych komplikacji, przed jakim stanąc musi interpretator owej zaskakująco wielowarstwowej prozy. Wspomniany problem, doprecyzujmy, natury narratologicznej, nieśmiało pozwoliłem sobie zasygnalizować w tytule mojego szkicu, tytule, który

$1 \quad$ S. Flukows ki, Zapach księżyca. Kraków 1981. W dalszej części szkicu cytaty z tego wydania oznaczać będę skrótem F. Liczby po skrócie wskazują stronice.

2 Pierwodruk opowiadań ukazał się w tomie Pada deszcz (Warszawa 1931). 
po kolejnej parafrazie sam przekształciłby się w parafrazę i brzmiałby wówczas następująco: Objaśnianie - zwierzęcych - marzeń sennych, lub, w wariancie asekuracyjnym (tudzież refutacyjnym): Próba objaśniania - zwierzęcych - marzeń sennych, dotąd nie zdradziłem bowiem, że Flukowski podjął się zadania w podwójny sposób skomplikowanego. Już samo wykreowanie realistycznej narracji zwierzęcej, $z$ wszelkimi tego usiłowania konsekwencjami (a więc z koniecznością odpowiedzi na pytanie, w jakim stopniu ludzki język zdolny jest do odtworzenia subiektywnego obrazu zwierzęcego świata, tego, co coraz częściej określamy dziś jako „Umwelt”3), wydaje się zadaniem wystarczająco trudnym, atoli autor Zapachu księżyca na tym nie poprzestaje i wykonuje narracyjny krok dalej, usiłując wniknąć pod powierzchnię nieświadomości zwierzęcej. Efektem takiego wysiłku sa dwa symetryczne opowiadania, które przykuły mój wzrok: Sen kota oraz Sen psa.

\section{Zagadka dla „Zwierzęcego” Freuda}

Sięgając po te niepozorne, kilkustronicowe zaledwie utwory, zawodowy czytelnik, a za takiego ma prawo uważać się literaturoznawca, powinien poczuć się zobligowany do, nazwijmy to tak, metodologicznego rachunku sumienia. Nagle może się bowiem okazać, że instrumentarium retoryczne, jakim $z$ mniejszą lub większą sprawnością operujemy, jeśli nie zawodzi w kontakcie $\mathrm{z}$ analizowaną tu proza (swoją drogą, przedstawiającą się jako wprawka, ćwiczenie stylistyczne na marginesie głównego nurtu twórczości pisarza ${ }^{4}$ ), to w dotkliwy sposób objawia swoje ograniczenia. Mówiąc metaforycznie, przypomina jemiołę pozbawioną kontaktu z soczystym wnętrzem pnia rozkwitającego drzewa. Ba, „drzewo” to umiemy trafnie zidentyfikować. Byłoby szczytem polonistycznej prostoduszności podejmować się interpretacji utworów literackich zawierających szczegółowe opisy snów - zwłaszcza gdy owe sny cechują się silnie podkreślonym charakterem onirycznym - bez przelotnego choćby flirtu z psychoanalizą. Tyle podpowiada filologiczny zdrowy rozsądek. Nietrudno jednak dostrzec, że w sytuacji tekstowej, w jakiej się znaleźliśmy, w sytuacji o znamionach pułapki interpretacyjnej, następuje konieczność rewizji dotychczasowych przyzwyczajeń hermeneutycznych, także tych zainspirowanych wszelkimi nurtami teorii psychoanalitycznej. Musi się tak stać z oczywistego powodu: jeśli psychoanaliza była (jest) dla literaturoznawców atrakcyjna, to najpewniej dlatego, iż zwykli oni traktować tekst literacki jako przejaw ludzkiej psychiki

3 Autorem tej kategorii jest niemiecki biolog J. von Uexküll. Jego koncepcję na gruncie kynologicznym rozwinęła twórczo A. H o row itz (Oczami psa. Co psy wiedza, myśla i czują. Przeł. M. Bug a j s ka. Warszawa 2010, rozdz. Umwelt. Z punktu widzenia psiego nosa).

4 O tym, że oba oniryczne opowiadania według badaczy stanowiły uboczny nurt działalności literackiej Flukowskiego, świadczyć może fakt, iż zostały pominięte w mikromonografii współtwórcy Kwadrygi. Zob. L. Szaru ga, Stefan Flukowski. W zb.: Obraz literatury polskiej XIX i XX wieku. Seria 6: Literatura polska w okresie międzywojennym. Red. I. Ma ci ejewska, J. Trznadel, M. P okra s e n owa. T. 4. Kraków 1993. Inaczej kwestię tę postrzega D. W oj d a (Perspektywizm $w$ pisarstwie Stefana Flukowskiego. „Ruch Literacki” 2013, z. 4/5. Artykuł przedrukowano w zb.: Stefan Flukowski i kult nowoczesności. Red. J. Madejski, B. M. Wolska. Szczecin 2015), według której Sen kota i Sen psa ilustrują poetykę perspektywizmu charakterystyczną dla całości tego wielogatunkowego dzieła. 
- psychiki, która sama w sobie upodabnia się do tekstu podatnego na interpretację; tymczasem utwory, jakimi się zajmujemy, przewrotnie uchylaja się przed próbą podobnej ingerencji. Ich sekret dałoby się chyba określić mianem postępującej symulakryzacji: i nie chodzi mi tu o to, że granica między rzeczywistościa snu (jakkolwiek niejednoznaczny byłby jej status) a jej przedstawieniem w prozie Flukowskiego stopniowo się zaciera, nie o to również, że dysponujemy szczegółową mapa pozbawioną terytorium. Terytorium najpewniej istnieje! Ale, jak dotąd, żaden człowiek, a więc ani pisarz, ani interpretator, nie ma tam wstępu, co skonstatować należałoby ze szczerym ubolewaniem.

Jeśli więc zdarzyło się tak, że nie dysponujemy kluczem, a na dodatek pojawia się zasadne podejrzenie, iż drzwi do nieświadomości zwierzęcej sa po prostu pozbawione zamka ${ }^{5}$, może pora zatem zatrzasnać okładki tomu Flukowskiego oraz wszem i wobec ogłosić własną bezradność. Oczywiście, nie mówię tego całkiem serio, choć problem zaiste wydaje się poważny. Należy go jednak nieco przeformułować. Rzecz jasna, nie jestem tak naiwny, by stwierdzić, że w analizowanych tu tekstach możemy doszukać się przejawów... psychiki zwierzęcej oraz że odnalezione w tej prozie zapisy marzeń sennych, które chcielibyśmy poddać interpretacji, doprowadza nas do świata wypartych i ocenzurowanych zwierzęcych pragnien. Takie rozumowanie, opierając się na ruchomym fundamencie wiązki analogii, z najważniejszą $z$ nich, zrównującą ludzki aparat psychiczny ze zwierzęca psyche (mimo wszystko pozwolę sobie pozostawić to określenie bez cudzysłowu), u swoich źródeł skażone byłoby tym, czego całkowicie pragnąbym uniknąć, tzn. - inwazją antropomorfizujących wyobrażeń. $\mathrm{W}$ takim razie powinno się zatem nasunąc pytanie: czy w wypadku opowiadań Flukowskiego w ogóle należałoby wspomnieć o mowie nieświadomości? Jeśli zaś tak, to czyjej? Skoro zaledwie przed momentem wykluczyliśmy zwierzęta, któż nam pozostaje: Flukowski? Narrator? A może, zgodnie z lacanowskim kierunkowskazem, powinniśmy skupić się wyłącznie na badaniu tej osobliwej przestrzeni wypełnionej przez pulsujący ruch signifiants, którą dałoby się chyba określić jako nieświadomość tekstu.

Wiele więc wskazuje na to, iż krótka dygresja metodologiczna zbliżyła nas do jednego z miejsc aporetycznych, których nieuchwytna topologia sprawia, że trudno w ich wypadku mówić o prowadzącej do nich wyrazistej drodze czy też szlaku. Nie musi to wszakże oznaczać konieczności odwrotu, chcielibyśmy wierzyć, że inter-

5 Aby odnaleźć odpowiedź na pytanie, „co i jak śni się zwierzętom” (czy zwierzęta śnią obrazami), spełniony powinien być przynajmniej jeden $z$ warunków: „musielibyśmy znaleźć sposób na przełożenie zapisu aktywności mózgu na obrazy... albo nauczyć zwierzęta ludzkiej mowy" (na stronie: http://wiadomosci.onet.pl/kiosk/nauka/o-czym-snia-zwierzeta, 1,3333010, wiadomosc.html /data dostępu: $1 \mathrm{~V}$ 2013〉). Natomiast sam fakt, że marzenia senne nie są wyłączną domeną człowieka, pozostaje raczej bezsporny - i mam tu na myśli nie tylko „nieprofesjonalne” obserwacje naszych zwierzęcych przyjaciół w trakcie snu (popiskiwanie, przebieranie nogami, co traktować można jako powtórne przeżywanie scen z życia dziennego), ale także niedawno przeprowadzony eksperyment naukowy w Massachusetts Institute of Technology: „Badacze zarejestrowali aktywność mózgu czterech szczurów nagradzanych w trakcie biegu w kołowrotku. Okazało się, że później, gdy gryzonie pogrążyły się we śnie, ich mózg wykazywał taką samą aktywność, a gałki oczne poruszały się w podobny sposób. Podczas kolejnych faz snu mózg szczurów funkcjonował tak, jak gdyby nadal trenowały w kołowrotku: naukowcy byli nawet w stanie określić, w jakim punkcie zabawki szczur znajduje się w danej chwili snu" (ibidem). 
pretacyjne środki niekiedy rzeczywiście uświęcają cel, że stanie się tak i tym razem. Na duchu może podtrzymywać fakt, iż na terytorium, które nie bez trudu staram się przemierzać, udaje się odnaleźć cudze ślady. Myślę tu np. o Jeanie Belleminie-Noëlu, jednym $z$ najbardziej cenionych przedstawicieli tendencji psychoanalitycznych we francuskich badaniach literackich, którego inspiracji wiele zawdzięczać będzie moje skromne studium. Co prawda, poszukiwania uczonego dotyczyły bezsprzecznego arcydzieła literatury światowej ${ }^{6}$, a co może nawet istotniejsze, w całości skupiały się na interpretacji marzeń sennych bohatera ludzkiego, mimo to jednak w dalszej części swoich dociekań pozwolę sobie regularnie nawiązywać do hermeneutycznych technik wypróbowanych przez właśnie tego badacza. Dzięki zaproponowanym przez niego regułom interpretacji chciałbym otrzymać odpowiedź na ekscentryczne $z$ pozoru pytanie: jak „psychoanalizować” sen psa i kota?

Jedną $z$ konsekwencji wprowadzenia zwierząt przez Flukowskiego na arenę tekstu literackiego, a następnie takiego pokierowania nurtem narracji, aby przed czytelnikami „rozsunąć tkaninę pracy sennej [...]”7 i starać się wydobyć stamtąd ukryty sens, sens snu (zwierzęcego), jest konieczność przeformułowania tego, co wiemy albo wydaje się nam, że wiemy, na temat pozycji powieściopisarza i psychoanalityka wobec problemu snu-tekstu (nie mylić z tekstem-snem; do tej zarysowanej przez Bellemina-Noëla opozycji za moment powrócę). O ile dotąd zastanawiano się nad relacjami między powieściopisarzem a psychoanalitykiem, nad próbą ich utożsamienia, lub też rozróżnienia, często dodając jeszcze jedno ogniwo hermeneutycznego łańcucha w postaci krytyka literackiego, o tyle w naszym granicznym przypadku należałoby wprowadzić dodatkową instancję, dzięki czemu wyłaniający się tu trójkąt interpretacyjny (nierównoboczny) przekształciłby się w kwadrat. Jak się domyślamy, jego czwartym wierzchołkiem powinien być ktoś, kto wyspecjalizował się w badaniu psychiki zwierzęcej: zoopsycholog albo jego bardziej współczesny etologiczny spadkobierca ${ }^{8}$.

Podkreślam ów (zoo)psychologiczny aspekt, gdyż koncepcja psychiki zwierzęcej, jaką dałoby się wypreparować $z$ analizowanej przeze mnie prozy Flukowskiego, na zasadzie swoistej inwersji przeciwstawia się redukcjonizmowi, jaki zaproponował XX-wieczny behawioryzm, zwłaszcza w swojej skrajnej postaci. Jeżeli w myśl tej teorii psychikę ludzką należałoby badać według reguł, które sprawdziły się w odniesieniu do zwierząt (lub jak kto woli: innych zwierząt $^{9}$ ), to w niemy sposób przy-

6 Zob. J. B elle mi n - N o ël, Jak „psychoanalizować” sen Swanna? Przeł. W. Kr z e m i e ń. W zb.: Psychoanaliza i literatura. Wybór, red., oprac. P. Dybe1, M. Głowiński. Gdańsk 2001. I. I w as i ó w, Słownik nieświadomości. Sny literackie po psychoanalizie. „Teksty Drugie” 1998, nr 1/2. Zob. też Dreams, Phantasms and Memories. Ed. W. O w c za r s ki, Z. Zi e m a n n. Gdańsk 2015.

7 S. Freud, Marzenia senne. W: Psychopatologia życia codziennego. - Marzenia senne. Przeł. W. Szew czuk. Warszawa 1987, s. 406.

8 Zob. np. W. G. Van der Kl o ot, Zachowanie się zwierzat. Przeł. I. Łu ka sz e w s ka. Warszawa 1971. - A. Manning, Wstęp do etologii zwierzat. Przeł. J. Pilarska-Obojska, E. Styczyńska-Jurewicz, T. Prus. Warszawa 1976. - B. Sadowski, J. A. Chmurzyński, Biologiczne mechanizmy zachowania. Warszawa 1989.

9 Zob. M. B a k ke, Między nami zwierzętami. O emocjonalnych zwiąkach między ludźmi i innymi zwierzętami. „Teksty Drugie” 2007, nr 1/2. 
jąc by trzeba założenie, iż to, co najistotniejsze dla sfery zachowań ludzkich, rozgrywa się w przestrzeni pomiędzy bodźcem a reakcją. Stąd już chyba niewielki krok może nie tyle w stronę zanegowania występowania jakichkolwiek zjawisk psychicznych, ile w kierunku ich skrajnej marginalizacji. Tymczasem polski pisarz - z premedytacja pomijam tu horyzont spekulacji, jak głęboko wnikał on w rewolucję, która stała się udziałem współczesnej psychologii - zdaje się wybierać dokładnie odwrotna trajektorię: to nie badania nad zwierzętami służą mu więc za model do tego, by jak najpełniej rozpoznać ludzką psyche, ale teoria arcyludzka, za jaką bez wątpienia uważać należy psychoanalizę, teoria, którą młody Flukowski najwyraźniej był zafascynowany, pomaga mu lepiej poznać/przedstawić sekretne życie zwierząt.

Nawet jeśli gest ów potraktować jako przejaw modernistycznie wysublimowanej antropomorfizacji, to jego konsekwencje mogą być zaskakujące: dzięki zasygnalizowanej tu transpozycji spoza kart książki Flukowskiego wychylałoby się zwierzę jako autonomiczny podmiot, w pełni zdolny do odczuwania cierpienia i przyjemności. Podmiot obdarzony złożoną psychika, w której ruchomych ramach mieściłaby się również rozległa sfera nieświadomości. To jasne, iż nie potrafimy tam wniknąć, nie musi to wszakże oznaczać, że sfery tej nie ma - zdaje się argumentować prozaik i zaraz potem usiłuje dokonać tego, co niemożliwe, stopniowo rozsuwając tkanine pracy zwierzęcego marzenia sennego. Tym samym, na długo przed Elizabeth Costello, protagonistką powieści południowoafrykańskiego noblisty, współzałożyciel Kwadrygi przekonywałby, że „nie istnieją granice wysiłku, jaki możemy i powinniśmy wkładać we wchodzenie w położenie innych [także tych, którzy śnią! - P. K.], nie ma granic dla współczującej wyobraźni”"10.

Na koniec tego nazbyt zapewne rozwiniętego wstępu pozwolę sobie sformułować myśl w intencji kontrowersyjną: nawet jeżeli nieuchronnym skutkiem przeprowadzonej tu próby uporządkowania przestrzeni interpretacyjnej miałoby być swoiste przesunięcie, przemieszczenie (Verschiebung) przedmiotu badań, w którego wyniku „to, co się śni zwierzętom”, ustapiłoby „temu, jak pisarze wyobrażają sobie to, co się śni zwierzętom", to i tak bez wahania warto podjać się gry hermeneutycznej. Należy jednak mieć przy tym świadomość, że u kresu naszej lektury analitycznej stoi nie Narrator czy Zwierzęcy Bohater albo jakaś ich osobliwa fuzja (przedstawione zwierze jako hipostaza pisarza?), ale skończona seria znaków zwana tekstem. I to ją chcielibyśmy „spsychoanalizować”.

\section{"Jak to jest być (śniącym) zwierzęciem?" ${ }^{11} \mathrm{O}$ fokalizacji}

Do rzeczy zatem. Gdy przyjrzymy się bliżej strukturze wybranego przeze mnie dyptyku opowiadań (Sen kota oraz Sen psa), mniej więcej w połowie każdego z nich dostrzeżemy szczelinę, wewnętrzne pęknięcie. Choć miejsce to jawi się na pozór jako przerwa w narracji ( $w$ jednym $z$ wypadków rozumieć to należałoby nader dosłownie: jako zwielokrotnioną interlinię, która rozszczepia kolumnę tekstu), chciał- 
bym, aby - paradoksalnie - to na nim właśnie przez moment skupiła się nasza uwaga. Może się bowiem okazać, że $\mathrm{z}$ kilku powodów jest to newralgiczny punkt narracyjnego (i narratologicznego) projektu, jakiego podjął się Flukowski. Jeśli uwzględnimy kryterium dynamiki fabuły, dostrzeżemy, iż w wytropionym tu miejscu nagle urywa się szlak zdarzeń; albo, nieco inaczej rzecz ujmując, zdarzenia zmieniają swoją konsystencję. Dzieje się tak na skutek snu, w jaki zapadają tytułowi bohaterowie obu utworów. Wraz z opuszczeniem kurtyny sennej, kurtyny powieki, fabuła „dzienna” (w obu przypadkach stanowiąca pierwszą część opowiadania) w całości ustępuje pola fabule „nocnej”, przestrzeń świadomości bohaterów zwierzęcych odsłania przed czytelnikami swój nieświadomy rewers, innymi słowy, w zależności od tego, po której stronie tekstowej „wyrwy” aktualnie się znajdujemy, przebywamy „na powierzchni poematu - i w środku”.

Symetrie można by z pewnością mnożyć, co najistotniejsze jednak, obie części opowiadań nie są „samotnymi wyspami”, ale fragmentami lądu, pomiędzy którymi autor starał się wybudować skomplikowaną sieć mostów. Ruch znaczeń, jaki się na nich odbywa, co interesujące, przebiega w obu kierunkach równocześnie. Jak to rozumieć? Funkcją inicjalnych partii utworów jest nie tylko wprowadzenie nas za próg świata przedstawionego, zaprezentowanie bohaterów oraz ukazanie łączących ich relacji (główne napięcie w obu fabułach ogniskuje się wokół duetu: zwierzę i jego pani/pan), ale także dostarczenie czytelnikowi, który już wkrótce będzie musiał przekształcić się w psychoanalityka, swoistego humusu - warstwy zdarzeń i znaczeń, z jakich w dużej mierze utkane będzie płótno marzenia sennego. Dzięki wytropieniu tych realistycznych pozostałości z życia na jawie, dzięki owej namiastce, w ogóle możliwy stanie się proces objaśniania marzenia sennego, ryzykowne przemierzanie przełęczy pomiędzy ukrytą myślą (Traumgedanke) a tym, co w ramach naszego eksperymentu lekturowego określilibyśmy jako treść jawną (Trauminhalt). Jak zatem widzimy, opowiadania Flukowskiego zostały skonstruowane w taki sposób, by czytelnik czuł się wyposażony w ich hermeneutyczną instrukcję obsługi: działa ona dzięki zasygnalizowanemu przed momentem dwukierunkowemu przepływowi znaczeń - nie tylko bowiem kontekst jawy pozwala nam na odkształcenie zniekształcajacej pracy tekstowego snu, ale i na odwrót, klucz do psychicznego życia bohatera zwierzęcego (a więc również do sfery jego ukrytych pragnień odczuwanych na jawie, sportretowanej w pierwszej części utworu) został zdeponowany głęboko pod warstwą marzenia sennego. Mamy zatem wyjątkową sposobność, by $\mathrm{z}$ bliska obserwować, jak to, co jawne, płynnie zamienia się w to, co ukryte, i vice versa. Oczywiście, nie wolno nam nawet na moment zapominać, że obcujemy tylko (aż) $z$ literaturą.

Aby oddalić zarzut, iż zarówno pisarz, jak i interpretator zbyt daleko posunęli się w głąb antropomorfizującego symulakrum, najwyższa pora zapytać, czy, a jeśli tak, to w jakim stopniu, fakt, że protagonistami obu onirycznych opowiadań autor uczynił zwierzęta, odcisnął się w fakturze narracji. Nieco inaczej to eksplikując, interesować nas będzie kwestia, czy w analizowanych tu utworach zdołamy doszukać się śladów wskazujących na próbę wprowadzenia przez Flukowskiego elementów percepcji rzeczywistości odmiennej niż ludzka. Jak się wydaje, nie można skutecznie odpowiedzieć na postawione pytanie - czy młodemu pisarzowi udało się choć w części nasycić nasz „apetyt na narracyjną przemianę? - bez uruchomienia 
terminu „fokalizacja”. Nie ma tu miejsca ani potrzeby, by szczegółowo referować całość teorii zaproponowanej przez francuskiego teoretyka literatury Gérarda Genette'a ${ }^{12}$, pamiętając więc tylko o wyróżnionych przez niego trzech podstawowych odmianach ogniskowania, inaczej zwanego fokalizacja (wspomniane warianty to, w zależności od stopnia wiedzy, jaka dawkuje czytelnikowi narrator, fokalizacja zerowa, wewnętrzna i zewnętrzna), chcielibyśmy sprawdzić, po której stronie tak wyznaczonej linii percepcyjnej lokowałyby się narracje zwierzęce Flukowskiego. Raz jeszcze rzucając okiem - nomen omen, wszak za Genette'em próbujemy powiązać kwestie narratologiczne z optyka - na strukturę Snu kota i Snu psa, a mówiąc precyzyjniej: ponownie dotykając tego osobliwego miejsca, które pozwoliłem sobie określić jako szczelinę, wewnętrzne pęknięcie, spodziewać by się można, że równocześnie $z$ przekroczeniem owego wewnętrznego progu po prostu coś musi zmienić się w budowie narracji. I takie procesy rzeczywiście zachodzą, nie są jednak chyba tak głębokie, jak można by się tego spodziewać. Ale po kolei.

Zdążyliśmy zauważyć, że w wypadku opowiadań Flukowskiego mówić należałoby o podwójnej symetrii. Pierwsza to symetria zewnętrzna - zgodnie z paralelna intytulacją, utwory te składają się na całość kompozycyjną, wzór, który śmiało dałoby się określić mianem „pendant”. Dodać tu można, że wybór tytułowych bohaterów, oczywiście, nie jest przypadkowy, przesądziło o nim kryterium domestykacji. Po prostu pies i kot to zwierzęta w najwyższym stopniu udomowione ${ }^{13}$, co ma i taki dodatkowy skutek, że najłatwiej nam jest (tym razem mówię o pisarzach) wyobrazić sobie / odtworzyć sposób odbioru świata właśnie $z$ ich perspektywy (a nie $z$ punktu widzenia ${ }^{14}$ pozostałych, dalszych człowiekowi „innobytów”). Istnieje jednak także i symetria wewnętrzna - każde $z$ analizowanych tu opowiadań składa się $\mathrm{z}$ dwóch równoległych części: pierwsza $\mathrm{z}$ nich rejestruje to, co udało się zwie-

Zob. A. Łe b kow sk a, Pojęcie fokus $w$ narratologii - problemy $i$ inspiracje. W zb.: Punkt widzenia wtekścieiwdyskursie. Red. J. Bartmiński, S. Niebrzegowska-Bartmińska, R. Nycz. Lublin 2004. - M. Re m b ow s k a - Pł u ci e n n ik: W cudzej skórze. Fokalizacja zmysłowa a literackie reprezentacje doświadczeń sensualnych. $\mathrm{W}$ zb.: Literackie reprezentacje doświadczenia. Red. W. Bole cki, E. Naw ro cka. Warszawa 2007; Poetyka intersubiektywności. Kognitywistyczna teoria narracji a proza XX wieku. Toruń 2012. - A. Żyźn iewska, Fokalizacja zwierzęca na przykładzie fragmentów prozy modernistycznej: „Nemroda” Brunona Schulza, „Dociekań psa” Franza Kafki oraz „Flusha” Virginii Woolf. W zb.: (Inne) zwierzęta maja głos. Red. D. D ą b row ska, P. Krupiński. Toruń 2011.

13 Zob. J. Pa g e, Jak koty widza świat i ludzi? Przeł. M. Kit te l. Warszawa 2010, s. 42-43: „Koty i psy to zwierzęta, które zostały udomowione w największym stopniu, przynajmniej według jednego prostego kryterium: to jedyne zwierzęta domowe, które nie muszą być zamykane, żeby nie uciekły. [...] Innym użytecznym kryterium jest to, że udomowione zwierzę powinno nie potrafić radzić sobie w naturalnym, to znaczy dzikim, środowisku". Co interesujące, badacz w dalszej części wywodu sam sobie przeczy, wskazując na wyrazistą różnicę, która oddala koci ród od wszelkich pozostałych udomowionych gatunków: „W przeciwieństwie do innych udomowionych zwierząt, koty nie stały się też w pełni zależne od ludzi. Praktycznie każdy kot domowy, do dziś dnia, może porzucić swoich właścicieli i całkiem nieźle poradzić sobie jako dachowiec w mieście, gdzie od czasu do czasu nakarmia go ludzie, albo jako samotny łowca w dziczy. Domowy kot, można by więc powiedzieć, nie jest całkiem udomowiony" (ibidem, s. 49).

14 Raz jeszcze zwracam uwagę na nieprecyzyjność sensualną tego określenia w odniesieniu do narracji usiłujących odtworzyć/imitować odczuwanie świata przez zwierzęta. 
rzęciu zaobserwować tuż przed zaśnięciem, druga - szczegółowo opisuje jego sen, aż do momentu ocknięcia się. Skupmy się na konsekwencjach narracyjnych tej drugiej odmiany symetryczności.

„Kot w nie do koń c a pustym mieszkaniu” - tak nieco żartobliwie można by scharakteryzować sytuację narracyjną, jaka zaistniała $\mathrm{w}$ pierwszym $\mathrm{z}$ analizowanych tu utworów. A niewielkie locum nie jest puste, gdyż niemal w całości wypełnia je swą ekspresywną krzątaniną kobieta przygotowująca się do wyjścia, najpewniej w celu intymnego rendez-vous. Ta niedługa, pozbawiona przełomowych zdarzeń scena, mająca w rzeczywistości status zagęszczonej deskrypcji, stanowi niemal wzorcowy przykład narracji personalnej: dyskretny narrator stara się zanadto nie ujawniać swego istnienia $i$, jeśli to możliwe, skrywa się za jedną $z$ postaci - w tym wypadku za „kocim grzbietem”. Mielibyśmy wszakże prawo zapytać: cóż to właściwie znaczy, że nasz narrator wie zaledwie tyle, ile w danym momencie jest w stanie zaobserwować bohater zwierzęcy? Zaobserwować? Istotnie, Flukowski, choć, oczywiście, nie mógł sobie tego teoretycznie uświadamiać, uruchamia tryby narracyjnego mechanizmu, który w naszym wypadku należałoby określić jako „fokalizację zwierzęcą" (a równocześnie - wewnętrzną, gdyż będziemy percypować świat $\mathrm{w}$ ramach horyzontu dostępnego bohaterowi ${ }^{15}$ ). Pamiętamy, iż główny cel tego wariantu fokalizacji stanowi próba jak najbardziej sugestywnej imitacji zwierzęcego sposobu postrzegania rzeczywistości, czego bezpośrednią konsekwencją bywa zazwyczaj przesunięcie narracyjnego punktu ciężkości na kwestię zmysłów. I dzieje się tak właśnie w interpretowanym tu opowiadaniu. Uprzedźmy jednak od razu, że opis kociego doświadczenia sensualnego, jaki sprezentował nam Flukowski, na pozór nie różni się diametralnie od ludzkiego modelu organizacji wrażeń zmysłowych (oraz od tego, jak sposób ów przedstawiany jest w literaturze).

Paradoksalnie, nie musi to wszakże dyskredytować Flukowskiego jako znawcy alfabetu zachowań zwierzęcych, a przynajmniej kocich. Jeśli uświadomimy sobie, że dla nocnego łowcy, którym - mimo jakże skomplikowanej drogi ewolucyjnej pozostaje kot, najistotniejszy ze zmysłów stanowi wzrok i zaraz potem słuch ${ }^{16}$ (odmiennie ta hierarchia sensoryczna przedstawiać się będzie np. u psów), wówczas wyraźna dominację doznań wzrokowych, o jakiej mówić należałoby w przypadku Snu kota, moglibyśmy zinterpretować jako przejaw zoologicznej erudycji młodego autora (inna rzecz, że kocie oczy widzą jednak w nieco odmienny sposób niż ludzkie, $z$ czego jeszcze w Dwudziestoleciu międzywojennym nie do końca zdawano sobie sprawę). O tym, że polski prozaik jest rzeczywiście uważnym obserwatorem kociego stylu bycia i postrzegania, świadczy również fakt, iż wykreowaną w utworze przestrzeń percepcyjna postanowił poszerzyć o bodźce odbierane przez pozostałe zmysły: tytułowego bohatera cechuje więc wyraźna nadwrażliwość na sferę dźwięków. Wśród nich znajdą się i takie, które $z$ łatwością mogłyby (niczym ultra- i infradźwięki) umknąć ludzkiemu uchu, np. dochodzący z oddali szelest robotniczych podeszew ścierających chodnik; w opowiadaniu znajdziemy także przynajmniej

15 Koncepcję G. Genette’a referuję za Re mbow s ką - Płu ci en nik (W cudzej skórze, s. 51-54).

16 Zob. Pa g e, op. cit., rozdz. Zmysły kotów. Dodać tu można, że w polskim przekładzie książki tego autora bezpowrotnie „zagubiła się” częśc sensualistycznej wymowy tytułu. W oryginale brzmiał on Do Cats Hear with Their Feet? 
dwie czytelne aluzje do „punktu obwąchiwania”17. Jak jednak wcześniej wspomniałem, impulsy te stanowią raczej kognitywny margines i nie zmieniają odczucia, że kobiecy buduar (oraz jego właścicielkę) oglądamy przede wszystkim kocimi oczyma. Igrając historycznoliterackimi asocjacjami, można by nawet powiedzieć, iż niewielkie opowiadanko autora Słońca $w$ kieracie stanowi skromny polski ekwiwalent jednego $\mathrm{z}$ rozdziałów Historii oka, zatytułowanego Kocie oko, skojarzenie zaś z dziełem Georges'a Bataille'a ${ }^{18}$ wkrótce okaże się o tyle zasadne, o ile tekst Flukowskiego w dużej mierze ufundowany został właśnie na napięciu erotycznym.

Skoro więc wiemy już, jak we Śnie kota (a w zasadzie w jego części poświęconej chwilom przed kocim uśnięciem) kształtują się relacje między narratorem a bohaterem - bohaterem, którego oko funkcjonuje niczym wyjątkowo sprawna kamera ${ }^{19}$, pozwalająca nam z uwagą obserwować miejsce akcji - zapytajmy, na czym w szczególności zatrzymuje się obiektyw narracyjny. Swoistym optycznym leitmotivem pierwszej partii opowiadania jest światło słoneczne, jakie przenika do buduaru przez szczeliny pomiędzy opuszczoną roletą a framugą okna, tym samym tworzac „dwa pasma”, w których „kręcą się tęczowe pyły kurzu” (F 21). Jak się wydaje, fascynują one kociego bohatera $z$ dwóch powodów: po pierwsze, stanowiąc źródło „słodyczy ciepła” (,jakże innego od ciepła pieca czy komina”, F 23), ale również wprowadzając element ruchu, którego po prostu nie jest w stanie zignorować żaden rasowy drapieżnik. O tym, jak bardzo istotny to fragment przestrzeni, niech świadczy fakt, że na zaledwie trzech stronicach, jakie zajmuje rekonstruowany tu opis, pojawia się on aż trzykrotnie. W ostatnim wypadku mówić można nawet o symbolicznym (a więc niedostępnym kotu) wymiarze swoiście przefiltrowanego solarnego światła:

Roleta ciągle była brązowa, w korytarzach słonecznej światłości wałęsały się jak pijane samotne pyły. Wpadały w pas świetlny i wychodziły zeń każdym punktem linii, będącej granicą między jasnością a mrokiem. [F 24]

Już wkrótce - wspólnie z bohaterem - spróbujemy przekroczyć inną, tym razem nieprzekraczalną barierę.

Jeśli pozwoliłem sobie (za narratorem) poświęcić tu nieco miejsca marginalnej z pozoru „strunie światła”, to uczyniłem tak dlatego, że - w moim przekonaniu -

17 Określenie S. Th e me r s o n a. Zob. K. Gil, „Wykład profesora Mmaa” Stefana Themersona jako dzieło oparte na watpieniu (tu zwłaszcza podrozdział Rzeczywistość pisana inaczej, czyli co widza termity. O fokalizacji). „Polisemia. Czasopismo Naukowe Antropologów Literatury Uniwersytetu Jagiellońskiego" 2012, nr 2. Na stronie: http://www.polisemia.com.pl/home/numer-2-2012-9/wykad-profesora-mmaa-stefana-themersona-jako-dzieo-oparte-na-wtpieniu (data dostępu: 12 II 2012). G. B a ta ille, Historia oka. Przekł., wstęp T. Ko m e nd a n t. Posł. T. S w o b o d a. Gdańsk 2010.

19 Gwoli rzetelności dodajmy, że koci aparat wzroku porównuje się raczej z aparatem fotograficznym: „Precyzja wzroku kota to efekt podobieństwa jego budowy do budowy aparatu fotograficznego w szczególności takiego staromodnego, który nie dość, że nie był w pełni automatyczny, to jeszcze wykorzystywał taki archaiczny wynalazek jak kliszę. Pierwsze, co musiał zrobić fotograf, by wykonać zdjęcie, to ustawić szerokość przesłony. Gdy jest ciemno, przesłonę trzeba otworzyć jak najbardziej, by wpuścić całe dostępne światło; przy silnym oświetleniu przesłonę należy skurczyć do rozmiarów małej dziurki. W oku - zarówno ludzkim, jak i kocim - funkcję przesłony spełnia źrenica. Źrenica kota potrafi rozszerzyć się do rozmiarów koła o średnicy pół cala” (P a g e, op. cit., s. 114). 
reakcja na nią wyjątkowo dobrze oddaje różnicę między ludzką a zwierzęcą odmianą percepcji. Na problem ten spojrzeć można również z medycznej perspektywy: gdyby jakiś człowiek uporczywie wpatrywał się, a nawet nie byłby w stanie odwrócić wzroku od wibrujących w przestrzeni mikroskopijnych pyłków kurzu, z pewnościa zdiagnozowane by to zostało jako sensoryzm - przejaw zaburzeń w odbiorze i przetwarzaniu bodźców zmysłowych (zakłócenie procesu tzw. integracji sensorycznej), tymczasem w zwierzęciu czujnie wodzącym wzrokiem za tym „znikającym punktem" bez wątpienia widzimy osobnika znakomicie wyposażonego przez naturę do odgrywania powierzonej mu roli. Można więc chyba śmiało rzec, że Flukowski, tak rozkładając optyczne akcenty, dobrze zdał test na bycie czujnym obserwatorem obyczajów wspólnoty zwierzęcej. Istnieje jednak i druga część (nie tylko optycznego) egzaminu. Aby uzmysłowić sobie, na czym ona polega, musielibyśmy podkreślić, że nasz bezimienny koci bohater reprezentuje ród męski (choć w tekście nie ma o tym mowy, winniśmy raczej założyć, iż nie jest kastratem). Dlaczego to takie ważne? Ano dlatego, że kot dzieli pomieszczenie (i życie!) $\mathrm{z}$ istotą nie tylko odmiennego gatunku, ale i odmiennej płci, co - przynajmniej teoretycznie - mogłoby nie pozostawać bez wpływu na kształt ich międzygatunkowej relacji. Czy odcisnęło się także w sferze spojrzenia? Żeby odpowiedzieć na to pytanie, przenieśmy się na moment do... łazienki pewnego wybitnego francuskiego filozofa.

\section{Flukowski versus Derrida}

Na początek przytoczmy znany fragment książki Jacques’a Derridy L'Animal que donc je suis:

Często pytam się o to, kim jestem i kim (w związku z tym) jestem w chwili, w której, schwytany nagi, przez spojrzenie zwierzęcia, na przykład przez oczy kota, popadam w istocie w problem, tak, w złą okoliczność [...], tłumiąc własne zakłopotanie. [...] Szczególnie że - muszę wyjaśnić - kot obserwuje mnie frontalnie nagiego, twarzą w twarz, i że jestem nagi stojąc przed oczami kota, lustrującego mnie od stóp do głów, najwyraźniej po to, by widzieć, nie wahającego się skoncentrować swój wzrok - tak, by uzyskać pewne pole widzenia - w kierunku mojej płci ${ }^{20}$.

Dlaczego przypominam poranna przygodę Derridy i jego kotki? Oczywiście, pamiętam o kolejności powstania tych - pod wieloma względami - odmiennych tekstów, ale gdybym miał spróbować wyobrazić sobie precyzyjny negatyw sceny sportretowanej przez ojca dekonstrukcji, to mógłby to być właśnie fragment narracji Flukowskiego. Mapa analogii wydaje się zaskakująco rozległa, tyle że mają one, by tak rzec, odmienny znak wartości. W eseju opartym na autobiograficznym doświadczeniu Derridy to nagi człowiek (mężczyzna), a staje się nagi w momencie zetknięcia się z cudzym wzrokiem, napotyka zwierzę (kotkę) i pod wpływem niespodziewanego skrzyżowania kroków oraz spojrzeń ${ }^{21}$ - które jednak, zdaniem Donny użytecznych. „Konteksty. Polska Sztuka Ludowa” 2009, nr 4, s. 13.

21 Interesująco o wzrokowych interakcjach ludzi i zwierząt pisał J. Berger (Po cóż patrzeć na zwierzęta? W: O patrzeniu. Przeł. S. Sikora. Warszawa 1999). Zob. też P. Armstrong, The 
Haraway, nie zdołało przekształcić się w spotkanie ${ }^{22}$ - czuje się zmuszony, aby nagle zreinterpretować swoją człowieczość. Choć jego błyskotliwe rozważania „nadgryzają" paradygmat antropocentryzmu, zwierzę, którego obecność uruchomiła spekulacyjną machinę, pozostaje „niemową, kimś - i tu pewnie powinniśmy wstawić znak zapytania - komu jednak nie przyznano łaski pełnej podmiotowości.

Czy sprawy potoczą się inaczej w drugim wypadku? Jeśli zgodzimy się na zaproponowane tu nieeuklidesowe reguły gry literackiej, scenę tę rzeczywiście będziemy mogli obejrzeć $z$ odwróconej niejako perspektywy: tym razem bowiem to człowiek - kobieta, przez moment w stanie, „w jakim ją Pan Bóg stworzył”, jest tac, która milczy, a czytelnikowi (zwłaszcza czytelnikowi, już teraz podkreślam jego płeć), dzięki sprawnemu działaniu mechanizmu fokalizacji zmysłowej, udaje się patrzeć na nią przez nieco przymrużone kocie ślepia. Dzięki tej „nieoczekiwanej zmianie miejsc" skromna prozatorska etiuda Flukowskiego niespodziewanie objawiłaby swój rys rewindykacyjny. Polski pisarz, w przeciwieństwie do francuskiego myśliciela (poddanego 〈nazbyt?〉 surowemu osądowi Haraway), najwyraźniej „był zaciekawiony tym, co kot mógł naprawdę robić, czuć, myśleć [...]” (podkreśl. P. K.), niestety, kłopot nasz polega na tym, że - w moim odczuciu - narrator „tym, co kot mógł naprawdę robić, czuć, myśleć [...]”, zaciekawiony był aż za bardzo. Jak to rozumieć? Może zamiast rozumieć, w tym wypadku należy po prostu patrzeć:

Kobieta stała znowu przed lustrem: wypinając się, oglądała piersi. Potem uniosła w górę obie ręce i jeszcze bardziej się przegięła. Brzuch wciągnięty w głąb, żebra nacisnęły skórę. Wspięta na palcach, trwała tak bez ruchu przez pewien czas. Obfite piersi podniosły się nieco, nabierając jędrności. Zaczęła się obracać to w tę, to w tamtą stronę. Wreszcie opuściła ręce i westchnęła. Potem rękami lekko dotykała brodawek; zadrżała. Nagle z pasją zgniotła piersi dłonią, twarz miała w skurczu, zgięta wpół, nogi w kolanach zwarte. [F 22]

Paradoks optyczny, na jakim ufundowano ową scenę, polega na tym, że kobieta, stając nago przed lustrem, oczywiście ma świadomość, iż jest i wkrótce będzie oglądana (zwierciadło metonimicznie imitowałoby tu pożądający wzrok kochanka), nie może wszakże wiedzieć, iż przypatruje się jej, erotycznie kontemplując, przynajmniej jeszcze jedna para męskich oczu. Jakkolwiek osobliwie by to zatem za-

Gaze of Animals. W zb.: Theorizing Animals: Re-thinking Humanimal Relations. Ed. N. Taylor, T. Signal. Leiden 2011.

22 Zob. D. H a r aw ay, When Species Meet. Minneapolis-London 2008, s. 19-21. Cyt. za: C z aj a, op. cit., s. 13-14: „Znalazł się [Derrida] niemal na krawędzi szacunku, gestu w stronę respecere, ale był wciąż uwięziony w kanonicznych tekstach zachodniej filozofii i literatury, a także w powiązanych z nimi obawach wobec bycia nagim w obecności kota. [...] Nie był zaciekawiony tym, co kot mógł naprawdę robić, czuć, myśleć, a może nawet otwierać się na niego, wówczas kiedy odwrócił się w jego stronę tamtego ranka. [...] Stąd też, jako filozof, tamtego ranka nie dowiedział się w końcu niczego więcej od, o, ze zwierzęcia, niż to, co wiedział na początku, obojętnie w jakim stopniu lepiej zrozumiał podstawowy skandal, jak i uporczywe przesądzenia swojego intelektualnego dziedzictwa”. Nieco inaczej te wzrokowe ludzko-zwierzęce relacje przedstawiać się będą np. w Dzienniku W. Gombrowicza. Według W. Boleckie go („Jak zachować się wobec krowy?”〈Wstęp do bestiarium Witolda Gombrowicza〉. W: W. Gombrowicz, Bestiarium. Wstęp, wybór, układ W. B ol e c ki. Kraków 2004, s. 14): „Sensem tego wątku jest dookreślenie ontologicznej odrębności pomiędzy człowiekiem a zwierzęciem”, zwierzęciem, dodajmy, które będąc - według autora Ślubu - pozbawione świadomości, nie jest zdolne do jakiejkolwiek formy dialogu. 
brzmiało, w tej części utworu narrator, pozostający w ścisłej unii z kocim bohaterem, przeobraża się we voyeura, czerpiącego dwuznaczną przyjemność - bliska stanu podniecenia erotycznego - płynąca $z$ samego procesu podglądania ${ }^{23}$ (dewiację tę zwykło się określać mianem „skopofilii”). Z pewnych względów jest to kluczowy fragment opowiadania Flukowskiego. Narracja, która zapowiadała się jako realistyczna (a nawet hiperrealistyczna) próba odtworzenia (symulowania) zwierzęcego sposobu percypowania rzeczywistości, nieoczekiwanie odsłoniła swoje antropomorficzne kulisy. W wyniku tej deziluzji zwierzę - przynajmniej przez moment - okazało się zaledwie atrapą, pokrytą futrem fasadą, która miała skrywać libidalne tęsknoty narratora męskiego. Jak widać, uczyniła to nie do końca skutecznie.

\section{Kot „na skraju załamania nerwowego”}

Jeśli w dotychczasowych rozważaniach starałem się skupić na tym, co i jak zwierzęcy bohater Flukowskiego - a my wraz z nim - obserwował, to teraz chciałbym przestawić nieco wektor naszych poszukiwań i zapytać: co dostrzegły jego „oczy szeroko zamknięte"? Innymi słowy, chciałbym przekroczyć granicę pomiędzy tekstową jawą a snem, granicę, która wewnątrz opowiadania sama w sobie przedstawia się jako limes - zwarty niczym transzeja jednozdaniowy akapit („Kot zapadł w ciężki, męczący sen”, F 24). Zobaczmy, co na nas czeka po drugiej stronie.

Na początek zakomunikujmy, że wypełniający drugą część opowiadania sen kota ukazany został jako rzeczywiste marzenie senne, przez co bynajmniej nie próbuję zasugerować - wbrew wcześniejszym obiekcjom - iż oto odnalazł się długo poszukiwany klucz do drzwi nieświadomości zwierzęcej (jeśli takowe istnieją), ale jedynie zwrócić uwagę na poetykę snu-tekstu, $z$ jakim teraz będziemy obcować. Jest ona biegunowo odległa od wszelkich satyrycznych czy znanych nam choćby z literatury dla dzieci wyobrażeń na temat tego, co się śni (lub może się śnić) zwierzętom. Kotu Flukowskiego nie przyśniła się zatem „wielka rzeka, pełna mleka / aż po samo dno" ${ }^{24}$, lecz odmienność rzeczywistości, w jakiej bohater przebywa tuż po opadnięciu kurtyny sennej, znalazła swoje odbicie nie tyle w fakturze narracyjnej (nadal więc obowiązują reguły narracji personalnej), ile w stylu znacznie różniącym się od poetyki inicjalnych partii utworu. Choć w jego onirycznej części spotykamy elementy nierealistyczne (dno odwróconej beczki, na którym balansuje kot, nagle przekształca się w powierzchnię księżyca - do tego motywu wkrótce powrócimy), autor zadbał, aby ich nie przedawkować, surrealistyczna aura wytwarza się raczej w wyniku intensywnego ruchu obrazów, przyspieszonego pulsu cza-

W cytowanym tu fragmencie można chyba nawet mówić o „spojrzeniu projekcyjnym”, przekształcającym ciało kobiece w obiekt. Według A. Jones - na którą powołała się I. Kow alc zy k (Ciało i wtadza. Polska sztuka krytyczna lat 90. Warszawa 2002, s. 162) - „samo spojrzenie jawi się jako narzędzie przemocy i penetracji. Jego ofiarą są kobiety - "te, które nie mają penisa"; ich ciała zostaja przedstawione jakby w uścisku spojrzenia: jako skrępowane, bez możliwości ucieczki przed penetrującym spojrzeniem". Zob. też A. J o n e s, Tracing the Subject with Cindy Sherman. W zb.: Cindy Sherman. Retrospective. Ed. A. Cruz, E. A. T. Smith, A. Jones. New York - London 1997, s. 34-35.

24 To, oczywiście, cytat ze słynnego Kotka J. Tu w i m a (w: Wiersze dla dzieci. Warszawa 1999, s. 70). 
su, w którym nie występują przerwy w dzianiu się. Wszystko to nie pozostało także bez wpływu na gramatyczny kształt analizowanych tu fragmentów: zapisano je krótkimi zdaniami, pośród których zdecydowanie dominuje parataksa, dodatkowo podkreślająca pewną równoległość oraz przypadkowość nocnych przygód, jakie stały się kocim udziałem. Przypadkowość to jednak pozorna, wystarczy bowiem spróbować odwrócić płótno marzenia sennego, by dostrzec, iż panuje w nim aż nazbyt wyrazista logika.

Zanim postaram się rozsupłać wielokrotnie krzyżujące się nici skojarzeniowe, skłębione li tylko po to, aby czytelnik mógł czerpać pełniejszą satysfakcję z pomyślnie przeprowadzonego (zoo)psychoanalitycznego śledztwa, już teraz chciałbym podkreślić, że zarówno Sen kota, jak i jego bliźniacza wersja - Sen psa (gdzie indziej), stanowią w moim odczuciu świadectwo rzetelnej znajomości dzieł Sigmunda Freuda. Tym samym kilkanaście lat po opublikowaniu słynnego cyklu artykułów Karola Irzykowskiego ${ }^{25}$ przybyłby nam jeszcze jeden rodzimy freudysta i nawet jeśli jego opowiadania $\mathrm{w}$ zestawieniu $\mathrm{z}$ dziełami bardziej prominentnych międzywojennych czytelników Wstępu do psychoanalizy (Witkacego, Schulza, Bolesława Micińskiego, Gombrowicza) jawić się moga jako utwory minorum gentium, to i tak o ich osobnym miejscu w naszym piśmiennictwie przesądzić powinien zastosowany w nich eksperyment. Eksperyment, jak starałem się udowodnić, narracyjnej (i narratologicznej) natury. Jeśli bowiem zgodzić się ze znawcami zagadnienia, wskazującymi na swego rodzaju nadrealistyczny niedosyt w obrębie polskiej prozy modernistycznej ${ }^{26}$, którego pośrednim skutkiem było stosunkowe ubóstwo motywów onirycznych, to - przyznajmy - Flukowski postarał się ów deficyt nadrobić ze znaczącym naddatkiem. $Z$ pewną przesadą można by nawet rzec, że udało mu się udowodnić, iż „sa rzeczy na niebie i na ziemi, o których śniło się"... zwierzętom. Wróćmy zatem do przerwanych na moment dociekań nad morfologia kocich marzeń sennych.

Przewodnikiem, swoistym cicerone, który pomoże nam zstąpić w głąb tego osobliwego narracyjnego konstruktu, imitującego zwierzęca nieświadomość, będzie słynny wiedeński psychiatra (myślę, że sam głęboko zdziwiłby się wizją tak ekscentrycznej peregrynacji, choć prywatnie dał się poznać jako wielki admirator zwierząt, konkretnie psów, a nawet widział je jako niezwykle pomocne w procesie diagnozowania pacjentó $w^{27}$ ). Wybór to o tyle naturalny, że właśnie w dziele Freuda, pod

K. Ir zy k ow ski, Freudyzm i freudyści. W: Pisma rozproszone. T. 1: 1897-1922. Teksty zebrała i oprac. J. Bahr. Kraków 1998. We wspomnianym artykule K. Ir zy k ow ski wykorzystał fragmenty swojego sprawozdania z obrad podczas Kongresu Neurologów, Psychiatrów i Psychologów Polskich, który odbył się w Krakowie w grudniu 1912 (Teoria snów Freuda. „Nowa Reforma” 1912, nr 590, z 21 XII, s. 12). Pierwodruk tego artykułu ukazał się w odcinkach na łamach „Prawdy” w roku 1913 (nry 2-6, 8-9).

26 Do podobnego wniosku doprowadzić może lektura hasła słownikowego poświęconego XX-wiecznej polskiej literaturze. Zob. M. B a ra now ska, Oniryzm. Hasło w: Słownik literatury polskiej XX wieku. Red. A. Brodzka [i in.]. Wrocław 1992. Zob. też H. D u bowi k, Nadrealizm w polskiej literaturze wspótczesnej. Poznań 1971. - Oniryczne tematy i konwencje w literaturze polskiej XX wieku. Red. I. Glatzel, J. Smulski, A. Sobolewska. Torun 1999.

27 Zob. Historia-Freud ijego PSY(choanaliza). Na stronie: http://www.dogoterapeuta.wortale.net/363-Historia-Freud-i-jego-PSYchoanaliza.html (data dostępu: 5 III 2013): „Freud słynął ze słabości do swoich dwóch psów rasy chow-chow, o imionach Lun i Jofi. Freud twierdził, że jego psy pomagały mu w diagnozowaniu pacjentów. Suczka Jofi zwykła przebywać wraz z terapeutą w jego gabinecie, 
którego wyraźnym wpływem, jak starałem się zasugerować, pozostawał autor Płomienia róży, należałoby się spodziewać swoistej instrukcji wykorzystanej przez młodego prozaika w trakcie „fastrygowania” tkaniny pracy sennej. Jako uważny czytelnik rozpraw twórcy psychoanalizy musiał Flukowski pamiętać, że marzenie senne objawiło się Freudowi przede wszystkim jako realizacja życzeń o silnym potencjale emocjonalnym, a cóż może równać się ładunkowi emocji z kręgiem zjawisk, którym patronuje Eros. To on rządziłby podziemnym światem psychicznego życia istot ludzkich, a analiza marzeń sennych byłaby pochodnia pozwalająca na częściowe choćby rozświetlenie libidalnych ciemności. Tak sprawy się miały (przynajmniej według Freuda) w przypadku człowieka. Moim zadaniem będzie teraz sprawdzenie, do jakiego stopnia koncepcja ta została przeniesiona na (grzasski) grunt zwierzęcego aparatu psychicznego (raz jeszcze można byłoby zatem mówić o niezwykle wyrafinowanym wariancie antropomorfizacji ${ }^{28}$ ), w którego funkcjonowanie mamy wgląd dzięki grze literackiej, jaką zaproponował nam Flukowski.

W kanonicznej dla naszych rozważań rozprawie Marzenia senne Freud przedstawił próbę klasyfikacji snów. Podzielił je na trzy kategorie „ze względu na spełnienie życzenia [...]": byłyby to więc marzenia senne ukazujące niestłumione życzenia w nie zamaskowanej formie; marzenia, które wyrażają stłumione życzenia w formie zamaskowanej; marzenia senne o stłumionym życzeniu, jednak zupełnie nie maskowanym lub maskowanym w sposób niedostateczny ${ }^{29}$. Zatrzymajmy się przy ostatniej z wyróżnionych przez psychoanalityka kategorii. Trop, który nas ku niej powiedzie, zdeponowany został w finalnej części obu opowiadań. Tym samym zbliżamy się do progu jeszcze jednej symetrii: podkreślmy, obie narracje urywaja się - i to niezwykle gwałtownie - dokładnie w momencie dotarcia przez bohatera zwierzęcego do kresu marzenia sennego, kresu, który zarazem jest początkiem, impulsem do hermeneutycznej kontynuacji (ze zrozumiałych względów musi się jej

zmieniając miejsce, w którym siedziała, w zależności od stanu emocjonalnego pacjenta. Suczka zwykle leżała koło kanapy Freuda lub blisko pacjenta tak, by być głaskaną. Gdy pacjent okazywał nadmierne napięcie, maszerowała w kąt pokoju, oddalając się. Pełniła też funkcję strażnika czasu słynnego ojca psychoterapii! Gdy czas sesji z pacjentem dobiegał końca, pies wstawał i udawał się w kierunku drzwi”.

28 Na kwestię tę zwrócił uwagę R. K oł o n i e c ki (Nowy prozaik: Stefan Flukowski. „Droga. Miesięcznik Poświęcony Sprawie Życia Polskiego” 1931, nr 12, s. 1006), jeden z pierwszych recenzentów debiutanckiej prozy Flukowskiego: „Zapewne, gdybyśmy postanowili zastosować tu jakieś kryteria naukowe, musielibyśmy stwierdzić, że koncepcja obu Snów polega na pewnej, w sensie psychologicznym, p e r s o n if i k a c j i zwierzęcia; ale i przed tym zarzutem stereotypowego antropomorfizmu w swej zoologii mógłby się Flukowski obronić. Podając rzeczywistość zjawiska sennego, psiego czy kociego, a więc wprawiając w ruch cały kalejdoskop domniemanej podświadomości zwierzęcej miał prawo zbudować nawet najswobodniejszą architektonikę imaginacyjną. Zwierzęta Flukowskiego są rozmyślną, celowo i oryginalnie przeprowadzoną stylizacją prawdy naturalistycznej takiej, jaką operował np. Dygasiński (dla celów wychowawczych) i, w mniejszej mierze, London (który stworzył właściwie dziwaczną metafizykę zwierząt, prawie bez psychologicznych komentarzy). W każdym razie sen jest u Flukowskiego tylko funkcją opisowa, jest artystycznym pretekstem, służącym autorowi do umotywowania obranego założenia ideowego: rzeczywistość - to medal, który ma nie jedną, lecz bardzo wiele stron odwrotnych". Zob. też J. J. Li p s ki, Marzenia senne i sny na jawie kotów, psów i ludzi. „Twórczość” 1958, nr 11 (jest to recenzja książki S. Flu ko wski e go Pada deszcz. Opowiadania. - Nowele (Wyd. 1, powojenne, rozszerz. Warszawa 1958〉).

Fr e u d, op. cit., s. 394. 
podjąć czytelnik, a nie $z$ nagła przebudzony podmiot). I choć na pozór podobny sąd można by wygłosić na temat dowolnego utworu literackiego (koniec lektury = poczatek analizy i interpretacji), swoiste nachodzenie na siebie w prezentowanych tu opowiadaniach dwóch płaszczyzn: snu-tekstu oraz tekstu-snu, sprawia, że proza ta staje się doskonałym wehikułem sensów metaliterackich, ale i literaturoznawczych. Na zasadzie jakiejś osobliwej mimikry przejmuje pewne właściwości marzenia sennego i podobnie jak ono nie ma sensu sama w sobie, lecz zyskuje go wyłącznie retroaktywnie, jako efekt interpretacji (a nawet interpretacji interpretacji). Interpretujmy zatem.

Paradoksalnie, powinniśmy zacząc od końca - i mam tu na myśli zarówno opowiadanie, jak i tkankę marzenia sennego szczelnie wypełniająca jego druga część. Pytanie, które w tym momencie się nasuwa, mogłoby brzmieć następująco: co sprawiło, że oniryczna podróż naszych bohaterów („podróż do kresu nocy”) urywa się przedwcześnie, dlaczego tak gwałtownie wyrzuceni zostają oni na powierzchnię jawy? Odpowiedzi, rzecz jasna, szukać by należało na klatkach przewijanego filmu-snu, ale i w warstwie kontekstu, której dostarczy nam część utworu poprzedzająca seans: tam spodziewać by się można dodatkowych informacji, niezbędnych w żmudnym dziele deszyfracji. Jak się jednak wydaje, jest i trzecie pomocne źródło: ponownie oddajmy głos Freudowi. Dokonując próby systematyzacji marzeń sennych, która pozwoliłem sobie zreferować w poprzednim akapicie, zwrócił on uwagę, że snom zaliczonym do trzeciej kategorii nieodłącznie towarzyszy lęk - lęk silny do tego stopnia, iż z reguły pod jego wpływem sny ulegają przerwaniu. Dowodził autor Totemu i tabu: „Bez wielkich trudności można wykazać, że treść wyobrażenia, która wywołuje lęk w marzeniu sennym, była kiedyś życzeniem, a następnie uległa stłumieniu" ${ }^{30}$. O uwadze tej warto pamiętać, bo już za chwilę może ona posłużyć jako klucz nie tylko do prześledzenia wędrówki ukrytych myśli ze starannie zaprojektowanej przez pisarza sfery nieświadomego ku świadomości, ale i do lepszego rozpoznania procesu, który za Freudem powinniśmy określić jako „Verdrängung”. Według tej teorii podszyty lękiem zwierzęcy sen odsłoniłby się przed nami jako świadectwo zablokowania oraz zepchnięcia do nieświadomości impulsów i pragnień, które za wszelką cenę szukałyby drogi powrotu. Nie porzucając zaś jeszcze przez moment kostiumu psychoanalityka, moglibyśmy postąpić krok dalej i stwierdzić, że skoro nasz tekstowy pacjent dotąd nie znalazł się, to - jeżeli nic rychło nie zmieni się w jego relacjach ze światem (i jego mieszkańcami) - już wkrótce znajdzie się w samym centrum kręgu zwanego nerwica.

Nie zbaczając zbyt szybko $z$ tego stromego szlaku, na którym interpretacja nieoczekiwanie przechyla się w stronę diagnozy, a nawet hermeneutyki nerwic (zaskoczenie to jednak pozorne, skądinąd wiemy bowiem, że przestrzeń marzenia sennego to terytorium, gdzie ściśle krzyżuja się ścieżki psychoanalizy i badań literackich), raz jeszcze odwróćmy płótno tekstowego marzenia sennego w poszukiwaniu przeoczonych symptomów. Ów gest odwrócenia wydaje się tutaj o tyle fortunny, o ile całość onirycznej fabuły wykreowanej przez Flukowskiego jawi się - po 
odkształceniu deformacji wprowadzonych przez pisarza, mających imitować tropologię snu - właśnie jako rewers dziennej biografii tytułowego bohatera. Biografia to może niezbyt urozmaicona, gdyż składałyby się na nią jedynie dwa rozdziały, poświęcone różnym formom głodu: zdobywaniu jadła oraz reprodukcji (rozdział trzeci - „odpoczynek, sen” - stanowiłby tu niejako ramę opowieści), lecz nie zmienia to faktu, że młody prozaik, występujący naprzemiennie jako behawiorysta i psychoanalityk (wbrew pozorom te żywioły w opowiadaniu „nie dziwią się sobie”), po raz kolejny objawia się jako pilny reporter pozaludzkiej rzeczywistości, ktoś, kto za cel postawił sobie ambitną próbę spojrzenia na świat z perspektywy zwierzęcej.

W jakim stopniu to próba udana (i czy w ogóle jesteśmy w stanie to zweryfikować)? Być może, wystarczy opinia nieśmiało zasugerowana wcześniej - kot Flukowskiego jako (potencjalny) neurotyk - by całość naszej interpretacyjnej konstrukcji rozbiła się o antropocentryczne rafy, myślę jednak, że takowa puenta nie do końca oddaje zaskakująca wielowarstwowość Snu kota. Opowiadanie to przypomina amalgamat, w którego obrębie młodemu autorowi udało się idealnie stopić heterogeniczne na pozór elementy, dzięki czemu - przyznam, to moje subiektywne wrażenie - istnieją w owym utworze momenty, kiedy czytelnik nie tylko dowiaduje się, jak to jest, gdy zachowujemy sie jak kot, ale także zyskuje wiedzę na temat tego, jak to jest być kotem, tak jak jest nim ów udomowiony ssak ${ }^{31}$. Do tego rodzaju scen zaliczyłbym np. fragment onirycznej części opowiadania poświęcony polowaniu na myszy: konstruując go, autor uczynił doprawdy wiele, aby ukazać nam odmienność zwierzęcego sposobu percypowania rzeczywistości, w tym celu znacznie poszerzając sensualistyczny horyzont. Czytając ów fragmencik, jesteśmy w stanie poczuć, iż kot jako wieczny łowca, „najlepiej ukształtowany przez ewolucję drapieżnik świata" ${ }^{2}$, w trakcie polowania nie tylko cały przemienia się we wzrok i słuch, ale też po prostu nie ma w jego ciele komórki, która nie skupiałaby się na przyszłej ofierze. Poluje więc każde ścięgno, każdy mięsień! Słyszy każde podbicie łapki, każdy wibrys! Za Jakiem Page'em moglibyśmy śmiało powiedzieć, iż dzięki Flukowskiemu na moment jesteśmy w stanie poczuć, "how cat hears with his feet”. Zaiste, niewiele znajdziemy w polskiej literaturze deskrypcji mogących się równać z tym opisem pod względem sensualistycznej gęstości, wielowymiarowości wywoływanych odczuć i doznań. Przyjdzie nam poczekać na Kota $w$ mokrej trawie Kornela Filipowicza, swoisty prozatorski hymn na cześć „miejsca, w którym materia świata jest tak cudownie zagęszczona i tak doskonale uformowana w ruchoma, żywą, widząca i czującą istotę"33.

Zabawa w kotka i myszkę stanowi jednakże, jak wspomniałem, zaledwie połowę marzenia sennego, które nawiedziło kota znużonego kobiecymi obrządkami swojej powabnej właścicielki. Już wkrótce - wciąż przebywamy na labilnym terytorium snu - role diametralnie się odwróca i ten, kto przed momentem zaledwie jawił się jako drapieżnik, teraz sam przeistoczy się w obiekt łowów. Wszystko to opisane zostało w sposób mający przypominać prawdziwy nocny sen (nie brak tu

31 Ponownie nawiązuję tu do eseju Nagela. Zob. też J. M. Coetze e, Elizabeth Costello. Przeł.

Z. B a tko. Kraków 2006, rozdz. Filozofowie i zwierzęta.

32 Page, op. cit., s. 65.

33 K. Filip ow ic z, Kot w mokrej trawie. W: Modlitwa za odjeżdżajacych. Warszawa 2004, s. 245. 
więc elementów nierealistycznych - metamorfoz postaci i krajobrazów), jednak czytelnik, który pobierał korepetycje u Freuda, bez większego trudu powinien potrafić wyłuskać spoza tropologicznej zasłony to, co zostało wyparte, zepchnięte do piwnic podświadomości. Nie będzie chyba zaskoczeniem, jeśli dodamy, że owo tajemnicze „to” także w wypadku naszego kota cechuje się charakterem seksualnym i jako takie zagraża koherencji jego świadomości. Niniejszym powróciliśmy do zarzuconego wątku nerwicy (histerii), który, w moim przekonaniu, jawi się jako najistotniejsza antropomorficzna wyrwa w animalistycznym pejzażu naszkicowanym przez Flukowskiego. Co ciekawe, pisarz, który, wznosząc swoją narracje, kierował się głównie regułami prawdopodobieństwa, pisarz, który umiejętnie połączył naturalizm $z$ konwencja - zaryzykuję neologizm - hipernadrealistyczną, równocześnie pełnymi garściami potrafił czerpać $\mathrm{z}$ rezerwuaru kulturowych klisz i stereotypów, oddajmy mu wszelako sprawiedliwość, twórczo je przekształcając. Śladem takiej gry byłaby np. ujawniona $\mathrm{w}$ trakcie snu lubieżność jako fundamentalny element kociej natury (koncept ten pobrzmiewa w naszej kulturze bodaj od czasów Arystotelesa), nieprzypadkowe okazuje się także miejsce onirycznej akcji: „Nagle [kot] spostrzegł, że dno, na którym siedzi, jest świecącym złoto księżycem” (F 25). Koty i księżyc, jak wiemy skądinąd, w europejskiej kulturze łączy wiele:

Koty z wielu powodów wiązano również z księżycem. Są to zwierzęta nocne, a w ciemności ich oczy świecą, jakby odbijał się w nich księżyc. Ponadto źrenice ich oczu rosną i kurczą się podobnie jak księżyc w ciagu miesięcznego cyklu. Te lunarne asocjacje prowadziły, oczywiście, do skojarzenia kotów również z cyklem menstruacyjnym, a dalej do ustalenia pewnych fizyczno-duchowych związków między kotami a kobietami, w które do dziś wierzy się w niektórych częśsiach świata ${ }^{34}$.

Lektura opowiadań Flukowskiego przekonuje, że terenem, na jakim można napotkać ślady podobnych wierzeń, jest także literatura modernistyczna. Oto bowiem kot, którego mamy możność podglądać przez lunetę jego własnego snu, nagle przerywa polowanie, zeskakuje $z$ chybotliwej powierzchni księżyca na ziemię, $w$ tym wypadku reprezentowana przez kamieniczne dachy śpiącego miasta, by udać się traktem wytyczonym przez instynkt. Szlak ów wybrukował pisarz symbolami: wspominałem już o księżycu, beczce, teraz na drodze naszego kota wyrosna „czerwone kominy” (jak powiedziałby Tadeusz Różewicz: „cały ten świat / dażzy jakby podświadomie / do przybrania kształtów fallicznych”35), pozostajemy więc w kręgu symboliki, której zabarwienie erotyczne kamufluje się jedynie po to, by tym bardziej je wyeksponować. Mimo to nie można odmówić kwadrygantowi daru zaskakiwania odbiorców. Choć igła kompasu erotycznego tytułowego bohatera zdaje się bezbłędnie wskazywać - i jemu, i czytelnikom - „kotkę na gorącym blaszanym dachu”, u kresu nocnej wędrówki czai się zaskoczenie. Zaskoczenie silne do tego stopnia, iż w ostatecznym rozrachunku rozrywa fakturę marzenia sennego. Co wywołało lęk śniącego bohatera? Freud nie miałby wątpliwości: coś, co było niegdyś życzeniem, a następnie uległo stłumieniu. Zobaczmy więc, czego potrafi pragnąc literacki kot, choć przed samym sobą nie chce się do tego przyznać:

35 T. Róże wi c z, Przygotowanie do wieczoru autorskiego. Warszawa 1971, s. 155. 
Wołała nań [kotka] coraz głośniej, coraz namiętniej, dziko. Zaczął powoli ku niej podchodzić, przystawał, wyrzucał z siebie przeraźliwy wrzask, ogon jego, teraz ogromny i puszysty, omiatał dach i kominy. Kotka ciężko dyszała, cała jak z brązu w poświacie miesiąca. Miauknął krótko, zwinął się do skoku. Nagle odwróciła ku niemu łeb i ujrzał, że ma twarz ludzką - jej. Przerażony odskoczył w bok i ocknął się. [F 27-28]

Abstract

PIOTR KRUPIŃSKI University of Szczecin

\section{WHAT DO ANIMALS DREAM ABOUT? STEFAN FLUKOWSKI AND PSYCHOANALYSIS}

The main aim of the article is an analysis of Stefan Flukowski's two early short stories, namely Sen kota (Cat's Dream) and Sen psa (Dog's dream), and considerations about the various difficulties with interpreting the pieces. The difficulties result from the narrative experiment used by Flukowski. The Polish writer, like many Inter-wars men of letters, was fascinated by Sigmund Freud's theory of psychoanalysis, especially by his concept of interpretation of dreams. Signs of the fascination are the short stories, being the subject of the article, which almost entirely make up a record of "literary dreams after psychoanalysis" (Inga Iwasiów's term). An additional interpretative "difficulty" with which an onirism researcher in literary text has to face is the fact that the protagonists of the pieces, the ones which dream, are animals. 